\title{
APPLYING SHADOWING TECHNIQUE TO IMPROVE STUDENTS' LISTENING ACHIEVEMENT
}

\author{
By: \\ Fitri Maini \\ SMKN 1 Empat Lawang, Empat Lawang South Sumatera \\ fitrimaini9@gmail.com \\ Rachmanita \\ English Language Education Study Program at FKIP Islamic University of \\ Ogan Komering Ilir Kayuagung, South Sumatera \\ ayuksulung2407@gmail.com
}

\begin{abstract}
This study tried find the students' improvement in listening achievement after having taught by using the shadowing technique. The method used was a quasi-experimental that involved two groups, namely the control group and experimental group. The population of this study was all the tenth graders of SMA Negeri 3 Unggulan Kayuagung with a total number of 198 tenth graders. Purposive sampling method was applied to select the sample involved 72 tenth graders. In collecting the data, try out the test was used to get the desirable questions that would be used in the pretest and posttest to both groups in the control and experimental group. To verify the hypothesis, the normality and homogeneity of the data were firstly analyzed before being continued to be analyzed by using a t-test. Based on the result of data analysis in an independent sample t-test, there were some findings found. First, the mean score of a posttest (75.56) in the experimental group was higher than the pretest (69.03) in the control group. Secondly, the value of $t_{\text {obtained }}$ was 2.77 at the significant level of $p<0.05$ in two-tailed testing with $\mathrm{df}=70$, the critical value of $\mathrm{t}_{\text {table }}$ was 1.99 . Since the value of $t_{\text {obtained }}$ was higher than $t_{\text {table, }}$, the null hypothesis (Ho) was rejected and the research hypothesis was accepted. In conclusion, it showed that the shadowing technique could improve the tenth-grade students' listening achievement at SMA Negeri 3 Unggulan Kayuagung.
\end{abstract}

Key words: shadowing technique, listening achievement

\section{INTRODUCTION}

As one of the four language

skills, listening is essential for

having good communication.

According to Mendelshon (1994) in
Gilakjani and Ahmadi (2011, p.977), listening influences a lot in the process of communication that takes up $40-50 \%$; speaking, $\quad 25-30 \%$; 
reading, 11-16\%; and writing, about $9 \%$. The data show that listening takes the largest number of activities than other skills in language learning. For that reason, the students must mastery listening to have good interaction.

Furthermore, listening, the active use of language, helps some one to access other person's meaning from speech (Cameron, 2001, p.40). Besides, Purdy (1997) in Gilakjani and Ahmadi (2011, p.978) explains that listening is the active and dynamic process of presenting, noticing, defining, memorizing, and answering to some expressed verbally and nonverbally, needs, concerns, and information given by other persons. In conclusion, listening is not an easy process because it requires the awareness of the listener to decode the message from the speaker through sounds as well as the grammatical patterns of the utterances that are being heard then interpret its meaning contextually so that the listener can give the response of what is being talked about.

However, the ability of listening the target language seems less important for a foreign language. Underwood (1989) in Gilakjani and Ahmadi (2011, p.981) mention that Some problems in listening to classroom learning are as follows; the inability to control the speed delivery, the limitation of vocabulary, the lack of contextual knowledge, the failure of recognizing the transition signal of speech, and so forth. Also, the learners have lack opportunities to explore listening task in the classroom learning. Buck (2001, p.6) also states that speech 
takes place in real-time, in the sense that the text is heard only once, and then it is gone. In short, there are some problems in listening to the classroom, namely limited vocabulary, less contextual knowledge, limited memorizing the speakers' message, and so on.

Furthermore, it is important to point out that teaching listening is not easy. As stated by Maxom (2009, p.195), students need to pay full attention and have a practice to the target language so that they can cope with the detail information of the language. Additionally, the selection of an appropriate technique in teaching listening is also crucial. Different learner indeed learns with different way. Hannel (2008, p.15) also says that student perceives knowledge and its difficulties differently. When the students' learning style does not match the way they are being taught, learning difficulties can be very easy to increase. For that reason, the teacher should find the appropriate teaching technique to teach listening in the classroom.

Many researchers and teachers have been investigating to find techniques to solve the problems in listening. The recent technique that has been used widely to improve listening skills is the shadowing technique. Lambert (1992) in Hamada (2012, p.4) defines that the shadowing as a paced, parrot-style auditory tracking task, conducted with headphones. The concept of the technique is to let the students mimic the native speaker sounds as much as possible after hearing the native speaker sounds. By having several practices on shadowing, students will 
get many opportunities to listen to how native speaker speaks so that students will be familiar with English words.

The main concept of shadowing is the repetition of the native speaker sounds. The fundamental of shadowing technique is to act the way of native speaker say something as resemble as possible (Luo, Yamauchi, and Minematsu, 2008, p.41). The shadowing gives many opportunities for learners to practice the language so that learners will be familiar with the language that is being learned. Tanaka (2004) in Horiyama (2012, p.114) describes that practicing the shadowing technique makes the students' listening skill (input skill), comprehension, and speaking skill (output skill) are highlighted.
There are four main steps of the shadowing technique according to Kadota and Tamai (2005) in Hamada (2012, p.5). The steps are as follows:

1) The teacher gives the script about recount text

2) The students listen to the whole script from the audio listening without looking at the script

3) The students hear the sounds once and write the answer in blanks of written script

4) The students shadow the sounds from the audio, paying attention with the pronunciation, intonation, and the speed without looking at the script (Mumbling)

5) Under the teacher's instruction, the students shadow the sounds by reading the script they have 
and check their understanding. (Parallel reading)

6) Students shadow the sounds without the text and try to carry with the way the native speaker says on the audio (Prosody shadowing)

7) Students try to get the idea from the passage while the final shadowing (Content shadowing)

8) Students respond some inquiries based on what they have heard.

According to Takizawa (2002) in Hamada (2012, p.4), the shadowing is beneficial to enhance the bottom-up process in listening, leading to acquiring more successful listening comprehension skills. Furthermore, students boost prosody, obtain concentration, and have natural speed. Tanaka (2002) in
Zakeri (2014, p.21) also adds that the shadowing as one of thirteen techniques used for interpreting training, affirming that shadowing is effective in developing a "good ear" for language, particularly in regards to accent and intonation, as well as improving overall listening ability. In other words, the shadowing technique has some benefits that allow the teacher to provide listening activity and increase their listening achievement .

\section{METHODOLOGY}

In conducting this study, a quasi-experimental method was used. The design would involve the experimental group and control group which each group was given pretest and posttest. Fraenkel, Wallen, and Hyun (2012, p.264) describe that a quasi-experimental 
design does not have randomly assigned groups. The independent variable in this study was the shadowing technique and the dependent variable was students' listening achievement.

In this study, the population that was all the tenth graders of SMA Negeri 3 Unggulan Kayuagung in the academic year 2014/2015 with the total number was 198 students. As a sample of the research, this study used a purposive sample. The considerations of choosing the sample were the same number of total students and the same teacher who teaches English in both classes. Based on the criteria, the writer used two classes from six classes available in the tenth graders of SMA Negeri 3 Unggulan Kayuagung. Flipping a coin technique was used to divide the experimental and control group for both classes. Therefore, X IPA4 was

as the experimental group and $\mathrm{X}$ IPA3 was as the control group. Besides, total number of students was 72 .

In this study, the researcher conducted the listening task in the form of a cloze test that consists of 50 questions. The test was conducted twice. The first test was pretest, and the second test was posttest. The pretest was used to check the students' scores before the experiment and posttest were used to check the students' scores after the treatment. Before defining the items of the pretest and posttest, the tried out the test was done to see the validity and the reliability of the test. The test was tried out to the known sample students of the tenth graders of SMA Negeri 3 Unggulan Kayuagung. The try out test was 
done at the same grade students as well as the same school where the research was conducted. Therefore, X IPA 2 was taken for trying out.

Content validity was used to measure the validity of the test and Kuder-Richarson (K-R) method was used to check the reliability of the test. To analyze the data, a t-test; paired sample t-test and independent sample t-test was used.

\section{RESULTS AND DISCUSSION}

The mean difference between the pretest and posttest in the experimental group was 14.44 , the standard deviation was 2.61 , the standard error mean was 0.43 , $\mathrm{t}_{\text {obtained }}$ was 33.17 at the significant level $\mathrm{p}<0.05$ in two-tailed testing with $\mathrm{df}=35$, and the critical value of $t_{\text {table }}$ was 2.03 . Since $p_{\text {value }}(0.000)$ was less than $\dot{\alpha}_{\text {value }}(0.05)$ and the value of $t_{\text {obtained }}$ (33.17) was higher than the critical value of $t_{\text {table }}(2.03)$, it meant that there was a significant difference in students' listening achievement after studying listening by using a shadowing technique. In other words, the shadowing technique was effective to be used in teaching listening. See Table 1.

Table 1

Summary of the Statistical Analysis on the Experimental Group

\begin{tabular}{lccc}
\hline & Pretest & Posttest & $\begin{array}{c}\text { Paired } \\
\text { Differences }\end{array}$ \\
\hline Mean & 61.11 & 75.56 & -14.44 \\
SD & 9.57 & 10.40 & 2.61 \\
DF & - & - & 35 \\
t-table & - & - & 2.03 \\
t-obtained & - & - & -33.17 \\
Significance & - & - & .000 \\
\hline
\end{tabular}

The mean difference between the pretest and posttest in the control group was 6.52 , the standard deviation was 2.62 , the standard error mean was $0.43, \mathrm{t}_{\text {obtained }}$ was 14.92 at the significant level $p<0.05$ in two-tailed testing with $\mathrm{df}=35$, and the critical value of t-table was 
2.03. Since $p_{\text {value }}(0.000)$ was less than $\dot{\alpha}_{\text {value }}(0.05)$ and the value of $t_{\text {obtained }}$ (14.92) was higher than the critical value of $t_{\text {table }}(2.03)$. It meant that there was a significant difference in students' listening achievement after studying listening by using the conventional method. See Table 2.

Table 2

Summary of the Statistical Analysis on the Control Group

\begin{tabular}{lccc}
\hline & Pretest & Posttest & $\begin{array}{c}\text { Paired } \\
\text { Differences }\end{array}$ \\
\hline Mean & 62.50 & & 6.52 \\
SD & 10.24 & 9.54 & 2.62 \\
DF & - & - & 35 \\
t-table & - & - & 2.03 \\
t-obtained & - & - & 14.92 \\
Significance & - & - & .000 \\
\hline
\end{tabular}

From those explanations above, it was interpreted that the shadowing technique was effective to improve the tenth graders' listening achievement of SMA Negeri 3 Unggulan Kayuagung. It was found that $t_{\text {obtained }}(33.17)$ was higher than $t_{\text {table }}(2.03)$ and $p_{\text {value }}$ (0.000) was less than $\dot{\alpha}_{\text {value }}(0.05)$. It meant that there was a significant difference in students' listening achievement after teaching listening by using shadowing technique in the experimental group. It showed that null hypothesis (Ho) was rejected and alternative hypothesis (Ha) was accepted.

The students in the experimental group had better progress because of practicing the shadowing technique continuously so that they could recognize the English words, having good pronunciation in terms of intonation and word stress. As a result, they could answer the questions easily. Shadowing technique encouraged them to be active listeners also because they needed to say what they heard. Besides, the students listened the English words correctly and knew the words so that they responded the questions easily than 
those students who were not taught using shadowing technique.

Furthermore, compared to the improvement of the experimental group, the improvement of the control group was still below the experimental group. It was found that $\mathrm{t}_{\text {obtained }}(14.92)$ was higher than $t_{\text {table }}(2.03)$ and $p_{\text {value }}(0.000)$ was less than $\alpha_{\text {value }}(0.05)$. It indicated that there was a significant difference in students' listening achievement.

Based on the result of the independent sample t-test, it was found that $t_{\text {obtained }}(2.77)$ was higher than $t_{\text {table }}(1.99)$ and $p_{\text {value }}(0.007)$ was less than $\dot{\alpha}_{\text {value }}(0.05)$. It meant that the null hypothesis (Ho) was rejected and the alternative hypothesis (Ha) was accepted. In other words, the shadowing technique was effective to improve the tenth graders listening achievement of SMA Negeri 3
Unggulan Kayuagung. The result of this study was in line with the research done by Hamada (2012) that was a success to find the effectiveness of shadowing on EFL learners' listening skills.

\section{CONCLUSION}

Shadowing technique with its benefits allows the students to practice language a lot by having mimicking and repeating the sounds they heard as good as possible. The activity in the shadowing technique provides many opportunities for the students to hear English words so that they will be familiar with them. Besides, the technique that can be done in the classroom, the shadowing technique can be done everywhere and every time. Moreover, the students were also commanded to do shadowing outside 
the classroom. The purpose of this activity was to build their motivation in learning English as well as improving their overall communicative skill, especially for listening that is considered as the most important skill in understanding speech.

\section{REFERENCES}

Buck, G. (2001). Assessing listening. Cambridge: Cambridge University Press.

Cameron, L. (2001). Teaching languages to young learners. Cambridge: Cambridge University Press.

Gilakjani, A. \& Ahmadi, M. R. (2011). A Study of factors affecting EFL learners' English comprehension and the strategies for improvement. Finland: Journal of language teaching and research, 2 (5) 977-988.

Hamada, Y. (2012). An effective way to improve listening skills through shadowing. The Language Teacher 36(1), 3-10.
Hannel, G. (2008). Success with inclusion; 1001 teaching strategies and activities that really work. Oxon: Routledge Taylor and Francis group.

Horiyama, A. (2012). The development of English language skills through shadowing exercise. Tokyo: Cosmopier.

Luo, D., Minematsu, N., Yamauchi, Y. \& Hirose, K. (2008). Automatic assessment of language shadowing through shadowing.

InternationalSymposium on Chinese Spoken Language Processing (ISCSLP). China: 978-1-4244-2944-4/08.

Maxom, M. (2009). Teaching English as a foreign language for dummies. West

Sussex: John Willey \& Sons, Ltd.

Zakeri, E. (2014). The Effect of Shadowing on EFL Learners' Oral Performance in Terms of Fluency. International Journal of English language teaching. 2(1), 21-26 : European Centre for Research training and development UK. 